\title{
Polyphenols: Nature's Gift as Dietary Phytoconstituents Against Different Human Ailments
}

\author{
Rojina Thapa ${ }^{1}$, Rambika Thapa ${ }^{1}$, Sunita Mahat ${ }^{1}$ and Rupak Thapa ${ }^{2 *}$ \\ ${ }^{1}$ Himalayan College of Agricultural Sciences \& Technology \\ ${ }^{2}$ NIST College, Banepa,
}

\begin{abstract}
Recently, researches and scientists are showing a lot of interests in bioactive compounds of plants and its products as these constituents are of high valued. Polyphenols are phytochemical constituents which are the integral components in plants and their products that are associated with defensive mechanism against infections and various oxidative stress by free radicals. Green tea, fruits, vegetables, cereals and red wines are rich sources of polyphenolic constituents which attributes prevention from infections and diseases because of its antioxidant properties, anti-diabetic properties, and radical scavenging properties. Oxidative stress which is the primary reason for different ailments in humans is due to the free radicals that are present even during the normal health condition. Polyphenolic acids like cinnamic acid, romarinic acid, stilbenes like resveratrol, flavonoids like catechin, taxifolin, quercetin, and lignans like sesamin, pinoresinol, podophyllotoxin etc. are found to be effective against wide range of human diseases like oxidative stress, cardiovascular disorder, neurodegenerative diseases, aging, and cancer. These phytoconstituents prevent the diseases and provide relieving sensation via different mechanisms.Here, the study shows the importance of polyphenols with respect to the relevance of human health. As there are the promising applications of various bioactive constituents in a wide range of disease, further research should be encouraged on the mechanism of action and bioavailability of polyphenols.
\end{abstract}

Keywords Polyphenols; Antioxidants; Bioavailability; Cardiovascular diseases; Diabetes; Aging; CancerIntroduction

Corresponding Author

Email-rup_thapa123@hotmail.com

\section{Introduction}

Plants produce different secondary metabolites among which polyphenols are of great importance, which is engaged in protection from various pathogens and radiation (1]. Polyphenols occur abundantly in fruits and vegetables that we consume in daily lives [1-3]. Food consists of polyphenols which attribute to the astringency, taste, coloration, and oxidative stability [3-4]. Past research and study strongly provide evidence that the constant dietary intake of food with exuberant polyphenols provide defence against various diseases like diabetes [5], cancer [6], cardiovascular diseases [7] and neurodegenerative diseases [8] (Figure 1) As the food with phenols and its derivatives are propitious to health, polyphenols and its derivatives demands are augmenting.

\section{Classification of Polyphenols}

Around 10,000 polyphenolic compounds have been discovered and identified [9]. Almost all
Polyphenols originate from a basic precursor, phenylalanine or shikimic acid. Phenylalanine is a substitute for methyl group of alanine whereas Shikimic acid is a cyclohexane, an anionic form of shikimate [9-10]. Normally, these precursors are associated with sugar residues in association with hydroxyl groups, carboxylic acids, organic acids, lipids, amines, etc. On the basis of phenol ring possessed by phenol and on the basis of structural components that they incorporate, phenols can be classified into different groups [11]. Most important classification of polyphenols includes phenolic acids, stilbenes, flavonoids, and lignans [9-11]. Illustration of different classes of polyphenols is provided by Table 1 .

\section{Phenolic Acids}

These are aromatic acid compounds which comprises a phenolic ring and an organic carboxylic acid framework. These are found 


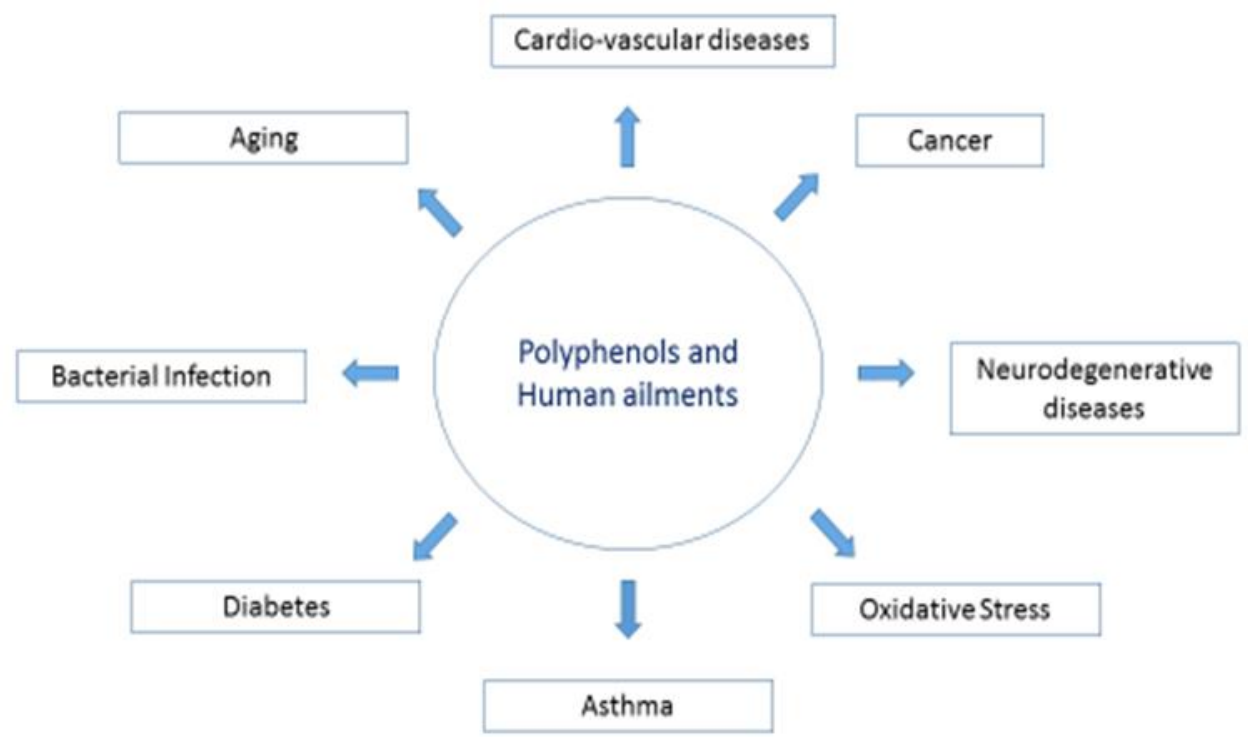

Figure 1: Polyphenols found abundantly as plant secondary metabolites occurring naturally in vegetables, fruits, cereals, green tea and red wines. Research and studies have shown that plant extracts are rich in polyphenolic constituents which are potent radical scavengers and impart great antioxidant activities providing significant protection against wide range of diseases like cardiovascular diseases, cancer, neurodegenerative diseases, aging, and diabetes.

Table 1. Types of polyphenols: Sources and functions

\begin{tabular}{|c|c|c|c|c|}
\hline Polyphenols & Food Sources & Examples & Functions & References \\
\hline $\begin{array}{l}\text { Phenolic } \\
\text { acids }\end{array}$ & $\begin{array}{l}\text { Straberries, coffee, nut, } \\
\text { vinegar, turmeric, } \\
\text { rosemary, cinnamon }\end{array}$ & $\begin{array}{l}\text { Cinnamic acid, } \\
\text { ellagic acid, } \\
\text { rosmarinic acid }\end{array}$ & $\begin{array}{l}\text { Antioxidant, Radical } \\
\text { scavengers and anti- } \\
\text { carcinogenic activities }\end{array}$ & $12-14$ \\
\hline Stilbenes & Grapes, red wine & Resveratrol & $\begin{array}{l}\text { Reduce oxidative stress, } \\
\text { anti-aging, antioxidants. }\end{array}$ & $15-16$ \\
\hline Flavonoids & $\begin{array}{lll}\text { Green } & \text { tea, } & \text { onion, } \\
\text { berries, } & \text { citrus } & \text { fruits. } \\
\text { Apple } & & \end{array}$ & $\begin{array}{l}\text { Catechin } \\
\text { epicatechin, } \\
\text { taxifolin, } \\
\text { quercetin }\end{array}$ & $\begin{array}{l}\text { Antimicrobial, } \\
\text { antioxidant } \\
\text { antidiabetic }\end{array}$ & $17-18$ \\
\hline Lignans & $\begin{array}{l}\text { Wide variety of plant } \\
\text { species }\end{array}$ & $\begin{array}{l}\text { Podophyllotoxin } \\
\text { and its derivatives }\end{array}$ & anticancer therapy & $19-20$ \\
\hline
\end{tabular}

copiously in fruits and vegetables and are further divided into two naturally occurring broad classes of hydroxybenzoic acids (Figure 2) and hydroxycinnamic acids (Figure 3) that are synthesized from the non-phenolic component of benzoic and cinnamic acid respectively [21]. The study has shown that the content of hydroxybenzoic acid in the case of an edible plant is usually low, except in the case of red fruits and onions. Clearly, hydroxycinnamic acids are found more commonly than hydroxybenzoic acids [22]. Phenolic acids are found in greater amount in dried fruits, beans, mushrooms, chicory, coffee etc. (21-22].<smiles>O=C(O)c1cccc(O)c1</smiles>

Figure 2: 3-hydroxybenzoic acid<smiles>O=C(O)/C=C/c1ccc(O)cc1</smiles>

Figure 3: hydroxycinnamic acid

\section{Stilbenes}

Stilbenes consists of two phenyl components united via two carbon Methylene Bridge. 
Stilbene may be either E-stilbene (trans-isomer] (Figure 4) or Z-Stilbene (cis-isomer) (Figure 5) (23]. E-stilbene consists a central ethane double bond replaced with phenyl groups on each carbon atoms of double bond whereas in Zstilbene it consists of cis ethane double bond substituted by a phenyl group on both carbon atoms of the double bond. Human diet contains a low amount of stilbene [24]. The most widely researched stilbene is resveratrol, which occurs naturally. Red wines and grapes comprise a higher number of stilbenes.

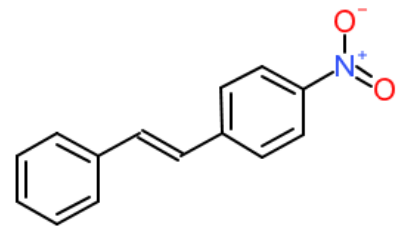

Figure 4: (E)-4-nitrostilbene<smiles>c1ccc2c(c1)ccc1ccccc12</smiles>

Figure 5: Z- Stilbene

\section{Flavonoids}

Flavonoids (Figure 6) are bioactive polyphenols which have low molecular weight with the 15-carbon skeleton, which comprises two phenyl rings and a heterocyclic ring. Flavonoids are the most indispensable group which is studied widely and they can again be classified into thirteen different subclasses [25].<smiles>O=c1oc2ccccc2cc1-c1ccccc1</smiles>

Figure 6: Flavonoids (benzyl pyrone)<smiles></smiles>

Figure 7: Anthocyanin

Over 4,000 flavonoids have been discovered and studied, most of which gives pigmentation to flour, fruits, and leaves. Flavonoids which are of eminent importance include flavonols, flavanones, isoflavones, flavones, and anthocyanins (Figure 7) [25-26].

\section{Lignans}

Lignans contain a structure which is derived from dimerization of two cinnamic acid residues [Figure 8). Lignans are derived from 2 phenyl propane moiety and sound plant source is vegetables, cereals, lentils and linseed [27]. Among the listed sources of lignans, linseed is the richest one. Major constituents of lignan include Seco iso lariciresinol and minor being matai retinol [27-28].

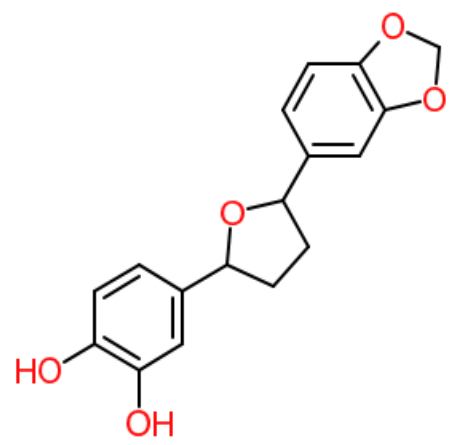

Figure 8: Lignans

\section{Recent Findings \\ Polyphenol consumption}

Regarding the dietary consumption polyphenols, little research has been done, though it is of immense importance. On a study carried out in the USA, flavonoid consumption was found out to be approximately $1 \mathrm{gm} / \mathrm{d}$ [29]. Among various groups of polyphenols, the flavonoid is studied widely. Daily intake of flavonoids has been estimated to be approximately $20 \mathrm{mg} / \mathrm{d}$ in European countries [30]. In Asian countries, there is significant consumption of soya which amounts to approximately $30 \mathrm{mg} / \mathrm{d}$ of isoflavones [30]. Dietary intake of polyphenols increases when vegetables and fruits like apple, pears, grapes etc. are consumed in the significant amount [2930]. The worldwide consumption of tea and coffee aids in consumption of hydroxycinnamic acids. People who drink several cups of tea or coffee might intake approximately $700 \mathrm{mg}$ hydroxycinnamic acids / d, whereas people who don't drink tea or coffee do not intake even 
$25 \mathrm{mg} / \mathrm{d}$ [31]. There is a variation on polyphenol intake and this is due to the individual preferences on different food items. In conclusion, polyphenol intake normally reaches $1 \mathrm{~g} / \mathrm{d}$ if people are subjected to adequate fruits and vegetables on daily basis [29-31].

\section{Bioavailability of Polyphenols}

The term "Bioavailability" is used to describe the perception of the speed and degree to which a metabolite approaches its spot action. In simple words, it is that portion of an ingested component which barges into the systemic circulation and distinct areas where it can employ its action [32-34]. The ultimate aim of bioavailability is to find out better-ingested components, active metabolites, and polyphenols that lead to the formation of the active metabolite.

Table 2. Important factors affecting bioavailability of polyphenols

\begin{tabular}{|c|c|c|}
\hline Factors & Examples & References \\
\hline & $\begin{array}{l}\text { Enzyme activity, } \\
\text { intestine and } \\
\text { colon microflora }\end{array}$ & 33,35 \\
\hline $\begin{array}{l}\text { Systemic } \\
\text { factors }\end{array}$ & $\begin{array}{l}\text { Age, physiol- } \\
\text { ogical condition, } \\
\text { and diseases }\end{array}$ & 33,36 \\
\hline Food factors & $\begin{array}{l}\text { Fat, fiber and } \\
\text { food matrix }\end{array}$ & 33,37 \\
\hline $\begin{array}{l}\text { Processing } \\
\text { factors }\end{array}$ & $\begin{array}{l}\text { Heat, homoge- } \\
\text { nization and } \\
\text { cooling methods }\end{array}$ & 33 \\
\hline $\begin{array}{l}\text { Other } \\
\text { components }\end{array}$ & $\begin{array}{l}\text { Bond with } \\
\text { polyph-enols or } \\
\text { proteins }\end{array}$ & 33,38 \\
\hline \multicolumn{3}{|c|}{$\begin{array}{l}\text { In order to demonstrate the biological } \\
\text { properties polyphenols essentially rely on } \\
\text { bioavailability. The structural framework plays } \\
\text { an important role in the rate at which these } \\
\text { polyphenols are ingested in intestines [39]. } \\
\text { Although some polyphenols are absorbed in } \\
\text { small intestine, a great number of polyphenols } \\
\text { that we intake cannot be readily absorbed in its } \\
\text { original nature. In order to be absorbed, } \\
\text { polyphenols have to be modified via intestinal } \\
\text { enzyme and microflora present in it [40]. } \\
\text { Polyphenols are hydrolysed in intestinal cells }\end{array}$} \\
\hline
\end{tabular}

and also the modification continues at liver via sulfation, glucuronidation, and methylation [41]. It is not the quantity of polyphenol that we consume determine the speed of absorption, but the chemical structure. It is a detoxification process that limits their toxic effects [39-41]. In addition to that, it facilitates biliary and urinary excretion by augmenting their hydrophilicity. Some of factors that affect bioavailability of polyphenols are listed on Table 2.

\section{Polyphenol as the natural antioxidants}

A molecule which has the capacity to inhibit the oxidation of other molecules is called antioxidants. During the oxidation process, there is the transference of electrons or protons from reference substance [42]. Oxidation process elicits free radicals which have the capability to start the deleterious reaction in the cell which ultimately deteriorates cell and in worse scenarios may lead to cell death [42]. Antioxidants, on the other hand, has the ability to terminate this deleterious reaction by scavenging the free radicals and by inhibiting the oxidation process [43]. Polyphenols are robust antioxidants and are depicted as freeradical scavengers [44]. This property is due to their hydrogen donating ability. Polyphenols provide $\mathrm{H}+$ atoms readily. This free radical scavenging property is mainly due to its immense reactivity of hydroxyl components [45].

\section{Polyphenols and cardiovascular Diseases}

Cardiovascular diseases are mostly seen as a causative factor for mortality in developed countries [46]. Different factors are responsible for the coronary heart diseases out of which environmental and hereditary are the most prominent ones [47]. Besides genetic factors, lifestyle and the way of living and food consumption play important role in case of cardiovascular diseases [48]. Lack of physical activities, unhealthy food habits, the intoxication of the body with cigarettes \&, alcohol and stress full life are the main 
contributing factors for the prevalence of cardiovascular diseases [49].

Different research and studies have shown that diet rich in polyphenols and flavonoids like beans, fruits and vegetables have curative and inhibitory effects against cardiovascular diseases [50-52). It was observed from the study that, there was $11 \%$ reduction from the adverse effect of cardiovascular diseases when three cups of black tea are taken daily [53-54).

Cardiovascular diseases are prevented by the polyphenols because it has the ability to ameliorate the activity of an enzyme and increase the bioavailability of nitric oxide for endothelium [47-49). Consumption of polyphenol-rich food products has a relaxing effect on the endothelium. Furthermore, food products rich in polyphenols like, flavonol has the effect of reducing hypertension and also lowers the blood pressure with improved function of endothelial tissues which prevents aggregation of platelet and lowers inflammation [55-56]. As black tea and cocoa contain high polyphenolic content, high drinking of these products lowers the risk of high blood pressure. [57-58]

\section{Polyphenols and cancer}

Cancer is a multi-step process. This includes initiation, development, and metastasis. Tumour may or may not cause deteriorating effects to the cell. Once the initiation starts, it inevitably progresses to malignancy imparting negative effects. Afterward, these cancerous cells transfer from one part to another by the process known as metastasis [59].

Polyphenols have the protective function and elicit the decrease in initial stage tumors. Different studies have shown that polyphenolic constituents like phenolic acids [60], stilbenes [61], flavonoids [62], phenol [63] and lignans [64] have proved to be effective against different human cancer cell lines. Polyphenol is to know for their inhibiting properties to cancerous cells via different mechanisms, which can be estrogen activity, antiproliferative activity, programmed cell death (apoptosis], Limiting oxygen to the cancerous cell, production and synthesis of detoxifying enzymes, alteration in cell signaling and regulating immunity-inducing factors in the host [65-66].

Cancerous cells are the results of carcinogens which are activated by the assertion of cytochrome P450, but the polyphenols have the tendency to affect this activity and have been identified as inhibiting factor which restricts this promotion of P450 expression [67-68]. Polyphenols induce phase II proteins which detoxify the toxicity and engender enhanced immunity against harmful xenobiotics [66]. A study in green tea has revealed that its components like catechins, theaflavins, and cherubins have promising potential against cancer [69]. They have found to restrict the formation of cancerous cells by the programmed cell death of prostate cancer cells. Similarly, Quercetin and resveratrol have found to inhibit all stages of cancer development and have found to be advantageous against skin, lung, colon, and breast cancer [70].

\section{Polyphenols and diabetes}

Diabetes is a condition which leads to increase in blood sugar level in the blood. According to $\mathrm{NLH}$, two main types of diabetes [type 1 and type 2) are common, type 2 being common [https://medlineplus.gov/diabetes.html].

Polyphenolic compounds work against diabetes by inhibiting the intestinal glycosidases and glucose transporter [72]. Different types of polyphenols like phenolic acids, stilbenes, flavonoids, phenol, and lignans are found to inhibit the S-Glut-1 transfer of glucose in the small intestine [72-73]. Resveratrol and saponins also have been found to detain the transport of glucose in the alimentary canal. Different studies have shown that quercetin, resveratrol, catechin, epicatechin, and epigallocatechin have antidiabetic properties [74]. Stilbene too has potent antidiabetic property and controls diabetes by modulating SIRT1 which is responsible for homeostasis of insulin and glucose [75]. Report on LLC-PK1 cells shows that anthocyanins and grape juice have inhibiting effect towards 
glucose mediated oxidative stress and cytotoxicity [76].

\section{Polyphenols and aging}

Different theories have been proposed regarding aging among which oxidative stress due to free radicals is one of the most approved ones [77]. Oxidative stress and detrimental effect due to it is present even under good health condition, but the damage rate elevates at the age increases due to weak repair mechanism at old age [78]. Aging is the consequence of the wide range of deleterious alteration in the cells as the age progresses ultimately leading to weakness and death [79]. Antioxidant and anti-inflammatory compounds have properties of reducing oxidative stress by scavenging the free radicals which work as effective anti-aging compounds [80]. Studies show that anthocyanins and grape polyphenol resveratrol show high scavenging potential with high antioxidant as well as antiinflammatory activities [84]. They are known to restricts the peroxidation of lipids and also inhibit cyclo-oxygenase which is inflammatory mediators [80-83].

Dietary intake rich in flavonoids and polyphenolic compounds like fruits and vegetables shows high antioxidant activity. Berries, beans, spinach, apple and green tea have been reported with high antioxidant contents and found advantageous against agerelated senescence and age-related problems [85-86]. Adequate consumption of polyphenols ameliorate the negative effects of aging and also have been found to delay the onset of aging [87].

\section{Polyphenols and Neurodegenerative Diseases}

Neurodegenerative diseases are the consequences of oxidative stress and free radicals which damage brain cells [88]. Medicine plus list 7 diseases under degenerative nerve diseases which include: Friedreich's ataxia, Alzheimer's disease, Parkinson's disease, lateral sclerosis, Huntington's disease, Amyotrophic, Lewy body disease and Spinal muscular atrophy.
Neurodegenerative diseases can be fatal even leading to the demise of patients.

Polyphenolic compounds are seen to have positive effects on nerve degenerative diseases as it has the power to scavenge the free radicals which impart detrimental effects in the body. Resveratrol, the integral component in grapes and wine, have been reported to scavenge free peroxide, hydroxide and other free radicals [90]. People who drink 2-3 glasses of red wine daily have been shown to $80 \%$ decrease in the evidence in Alzheimer's disease [91]. Drinking green and polyphenolic-rich diet act potent agent for neuroprotection via cell signaling, programmed cell death [apoptosis] proliferation and differentiation [92]. Green tea has been found effective against Parkinson's diseases by inhibiting MPTP (N-methyl-4phenyl-1, 2, 3, 6-tetrahydropyridine), which is the integral factor for Parkinson's diseases [9193].

\section{Conclusion}

This review tries to outline the current understanding of polyphenols and its biological beneficial effects in human health. Dietary intake of polyphenolic compounds daily imparts important protection against wide range of detrimental diseases like cardiovascular disorders, diabetes, cancer, aging and nerve-degenerative diseases. This positive advantageous aspect of polyphenols on human health depends on their intake and their bioavailability. It is well documented through studies and researches all around the world that polyphenols have the wide range of applications in human health but still the mechanism of action of various polyphenolic constituents are yet to be understood. This positive advantageous aspect of polyphenols on human health depends on their intake and their bioavailability. The role of polyphenols in human health is a promising area of the research study. This review outlines the promising wide range application of polyphenolic compounds and prominent hope for chronic detrimental human diseases. 


\section{References}

1. Kadioglu OE, Wu CS: Polyphenols-Versatile Weapons in Plants and Human Beings. Med Aroma Plant. 2015 04(04) http://dx.doi.org /10.4172/2167-0412.1000e159

2. Yang J, Dwyer J, Peterson J: Polyphenols in Foods. Nutrition Today, 2016 51(6), 290-300. http://dx.doi.org/10.1097/nt.0000000000000 183

3. Sutapa B, Vansh K, Vaibhav A, Gopa R: Polyphenols derived from four indigenous Indian fruits for cancer chemoprevention and chemotherapy. J Med Plant Res. 2016 10(46):838-847. http://dx.doi.org/10.5897 /jmpr2016.6288

4. Coulson C, Davies R, Lewis D: Polyphenols in plant, humus, and soil. J Soil Sci. 1960 11(1): 20-29. http://dx.doi.org/ 10.1111/j.1365-2389.1960.tb02198.x

5. Xiao J, Hogger P: Influence of Diabetes on the Pharmacokinetic Behavior of Natural Polyphenols. Curr Drug Metab. 2014 15(1): 2329. http://dx.doi.org/10.2174/138920021466 6131210142614

6. Branco CdS, Rodrigues TS, Lima ÉD, Salvador MPolyphenols-rich extract from Araucaria angustifolia: differential mechanisms on cancer and normal cells. (2015). Cancer Cell $\mathcal{E}$ Microenvironment. 2: e858. http://dx.doi.org/10.14800/ccm.858

7. Yamada $H$, Watanabe $H$ : Tea polyphenols in preventing cardiovascular diseases. Cardiovasc Res. 2007 73(2):439-440. http://dx.doi.org/10.1016/j.cardiores.2006.1 1.008

8. Barreto G, Guedes R: Polyphenols and neurodegenerative diseases. Nutr Neurosci. 2012 15(3):92-93. http:/ /dx.doi.org/10.1179/ 12z.00000000034

9. Weichselbaum E, Buttriss J: Polyphenols in the diet. Nutr Bull. 2010 35(2):157-164. http:/ / dx.doi.org/10.1111/j.14673010.2010.01821.x

10. El-Gharras H: Polyphenols: food sources, properties and applications - a review. Int J Food Sci Tech. 2009 44(12):2512-2518. http:/ / dx.doi.org/10.1111/j.13652621.2009.02077.x

11. Harborne J, Sherratt H: Plant polyphenols. 3. Flavonoids in genotypes of Primula sinensis. Biochem J. 1961 78(2):298-306. http://dx.doi. org /10.1042/bj0780298

12. Fernandes V, Domingues $V$, de-Freitas $V$, Delerue-Matos C, Mateus N : Strawberries from integrated pest management and organic farming: Phenolic composition and antioxidant properties. Food Chem. 2012 134(4): 1926-1931. http://dx.doi.org/ 10.1016/j.foodchem.2012.03.130

13. Eating nuts reduces the risk of death from a range of diseases. (2015). Nursing Standard,
29(44):14-14. http://dx.doi.org/10.7748 /ns.29.44.14.s15

14. Özcan M, Arslan D: Antioxidant effect of essential oils of rosemary, clove and cinnamon on hazelnut and poppy oils. Food Chem. 2011, 129(1), 171-174. http://dx.doi.org/10.1016/j.foodchem.2011. 01.055

15. Kanner J, Frankel E, Granit R, German B, Kinsella J: Natural antioxidants in grapes and wines. J Agri Food Chem. 1994 42(1):64-69. http://dx.doi.org/10.1021/jf00037a010

16. Bin D: Phenolic content and antioxidant activity of wine grapes and table grapes. $J$ Med Plants Res. 2012 6(17). http://dx.doi.org/10.5897/jmpr12.238

17. Ramasamy C: Potential natural antioxidants: adjuvant effect of green tea polyphenols in periodontal infections. Infect Disord Drug Targets. 2015 15(3):141-152. http://dx.doi.org /10.2174/1871526515666150831144528

18. Haddad P, Eid H: The Antidiabetic Potential of Quercetin: Underlying Mechanisms. Curr Med Chem. 2017 24(4):355-364. http:/ /dx.doi.org/10.2174/092986732366616 0909153707

19. Fuss E: Lignans in plant cell and organ cultures: An overview. Phytochemi Rev. 2003 2(3):307-320. doi:10.1023/b:phyt.0000045500. 56476.f5

20. Dewick P, Jackson D: Cytotoxic lignans from Podophyllum, and the nomenclature of aryltetralin lignans. Phytochem. 1981 20(9): 2277-2280. http://dx.doi.org/10.1016/00319422(81)80129-x

21. Cabrita M, Dias C, Freitas A: Phenolic Acids, Phenolic Aldehydes and Furanic Derivatives in Oak Chips: American vs. French Oaks. S Afr J Eno Vitic. 2016 32(2). http://dx.doi.org/10.21548/32-2-1380

22. Korneev S: Hydrocinnamic Acids: Application and Strategy of Synthesis. Synthesis. $\quad 2013 \quad$ 45(08):1000-1015. http:/ / dx.doi.org/10.1055/s-0032-1318475

23. Kozłowska M, Czekała L: Stilbenes and their role in disease resistance. Prog Plant Prot. (2017) 57:27-35. http://dx.doi.org/ 10.14199/ppp-2017-004

24. Király-Véghely Z, Kátay G, Tyihák E, Merillon J: Separation of stilbene isomers from red wine by overpressured-layer chromatography. J Planar Chromat. 2004 17(1):4-8. http://dx.doi.org/10.1556 /jpc.17. 2004.1.1

25. Oka M: Pharmacological studies on flavonoids. Folia Pharmacologica Japonica. 1961， 57(5):566-576. http://dx.doi.org/ 10.1254 / fpj. 57.566

26. McClendon JH: Comparative Biochemistry of the Flavonoids. In The Flavonoids (Eds.) Harborne JB Bioscience 1969 19(2) :181-182. http:/ /dx.doi.org/10.2307/1294691 
27. Phytochemistry and biology of lignans. Phytochem 2002 61(3):357. http://dx.doi.org/ 10.1016/s0031-9422(02)00311-4

28. Iwakami S, Wu J, Ebizuka Y, Sankawa U: Platelet Activating Factor (PAF) Antagonists Contained in Medicinal Plants: Lignans and Sesquiterpenes. Chem Pharma bull. 1992 40(5):1196-1198. http://dx.doi.org/ 10.1248 /cpb.40.1196

29. Celep G: Polyphenol Consumption and Metabolic Diseases. J Nutr Disorder Ther. 2012 03(01). http://dx.doi.org/10.4172/21610509.1000e106

30. Malenčić D, Cvejić J, Miladinović J: Polyphenol Content and Antioxidant Properties of Colored Soybean Seeds from Central Europe. J Med Food. 2012 15(1) :89-95. http://dx.doi.org/10.1089/jmf.2010.0329

31. Graham H: Green tea composition, consumption, and polyphenol chemistry. Prev Med. 1992 21(3):334-350. http://dx.doi. org /10.1016/0091-7435(92)90041-f

32. Shivashankara K, Acharya S: Bioavailability of Dietary Polyphenols and the Cardiovascular Diseases. Open Nutraceuticals J. 2010 3(1) :227-241. http://dx.doi.org/ 10.2174/1876396001003010227

33. Bohn T: Dietary factors affecting polyphenol bioavailability. Nutr Rev. 2014 72(7):429-452. http://dx.doi.org/10.1111/nure.12114

34. Factors Influencing the Bioavailability of Drugs. (1984). Inpharma. 462(1) :3-3. http://dx.doi.org/10.1007/bf03316141

35. Kumar N: Green tea polyphenols in the prevention of colon cancer. Front Biosci. 2007 12(1):2309. http:/ / dx.doi.org/10.2741/2233

36. Williamson G: Bioavailability and health effects of cocoa polyphenols. Inflammopharmacology. 2009 17(2):111-111. http:/ /dx.doi.org/10.1007/s10787-008-8030$\mathrm{y}$

37. Ho CK, SiuWai C, Fung MS, Benzie IFF: Tea polyphenols: absorption, bioavailability and potential toxicity. $\mathrm{CAB}$ Reviews: Perspectives in Agriculture, Veterinary Science, Nutrition and Natural Resources 2017, 12(002). http://dx.doi.org/10.1079/ pavsnnr201712002

38. Skrabanja V, Lærke HN, Kreft I: Proteinpolyphenol interactions and in vivo digestibility of buckwheat groat proteins. Pflügers Arch. 2000 440(S1):R129-R131. http:/ / dx.doi.org/10.1007/s004240000033

39. Carbonaro M, Grant G, Pusztai A: Evaluation of polyphenol bioavailability in rat small intestine. Eur J Nutr. 2001 40(2):84-90. http://dx.doi.org/10.1007/s003940170020

40. Williamson G, Clifford M: Role of the small intestine, colon and microbiota in determining the metabolic fate of polyphenols. Biochem Pharmacol. 2017 139: 24-
39 http://dx.doi.org/10.1016/j.bcp.2017. 03.012

41. Wang P, Heber D, Henning S: Quercetin increased bioavailability and decreased methylation of green tea polyphenols in vitro and in vivo. Food Funct. 2012 3(6):635. http://dx.doi.org/10.1039/c2fo10254d

42. Sharma A, Agrawal P, Bhatt J: Polyphenols: An excellent source of antioxidants for human health. Biotech Today 2014 4(1):15. http://dx.doi.org/10.5958/2322-0996.2014. 00012.x

43. Samman S: Antioxidants and Public Health. Antioxid Redox Signal. 2010 13(10):1513-1515. http://dx.doi.org/10.1089/ars.2010.3423

44. Elford H, Feinstein D, DeVries G: A Unique Polyphenol Free Free Radical Scavenger Didox's Ability to Treat Multiple Sclerosis. Free Radic Biol Med. 2010 49:S155. http://dx.doi.org/10.1016/j.freerad biomed. 2010.10.435

45. Rice-Evans C: Plant polyphenols: free radical scavengers or chain-breaking antioxidants?. Biochem Soc Symp. 1995 61:103-116. http://dx.doi.org/10.1042/bss0610103

46. Zhang Y: Cardiovascular diseases in American women. Nutr Metab Cardiovasc Dis. 2010 20(6):386-393. http://dx.doi.org/ 10.1016/ j.numecd.2010.02.001

47. Ginter E, Simko V: Plant polyphenols in prevention of heart disease. Bratisl Med J. 2012 113(08):476-480. http://dx.doi.org/ 10.4149/bll_2012_105

48. Pellegrino D: Antioxidants and Cardiovascular Risk Factors. Diseases. 2016 4(1):11. http://dx.doi.org/10.3390/diseases 4010011

49. Hsia J: Managing cardiovascular risk factors: Trial evidence in women. Nutr Metab Cardiovasc Dis. 2010 20(6):445-450. http:/ /dx.doi.org/10.1016/j.numecd.2010.01 .010

50. Macini M, Stamler J: Diet for preventing cardiovascular diseases. Nutr Metab Cardiovasc Dis. $2004 \quad$ 14(1):52-57. http:/ / dx.doi.org/10.1016/s0939-4753(04) 80047-4

51. Hamer M, Mishra G: Dietary patterns and cardiovascular risk markers in the UK Low Income Diet and Nutrition Survey. Nutr Metab Cardiovasc Dis. 2010 20(7):491-497. http://dx.doi.org/10.1016/j.numecd.2009.05 .002

52. Hu T, Bazzano L: The low-carbohydrate diet and cardiovascular risk factors: Evidence from epidemiologic studies. Nutr Metab Cardiovasc Dis. 2014 24(4):337-343. http://dx.doi.org/10.1016/j.numecd.2013.12 .008

53. Yamada $H$, Watanabe $H$ : Tea polyphenols in preventing cardiovascular diseases. Cardiovasc Res. 2007 73(2):439-440. 
http:/ / dx.doi.org/10.1016/j.cardiores.2006.1 1.008

54. Pooja B, Deepa K: Green tea catechins: defensive role in cardiovascular disorders. Chin J Nat Med. 2014 11(4):345-353. http://dx.doi.org/10.3724/sp.j.1009.2013.00 345

55. Davinelli S, Scapagnini G: Polyphenols: a Promising Nutritional Approach to Prevent or Reduce the Progression of Prehypertension. High Blood Press Cardiovasc Prev. 2016 23(3):197-202. http://dx.doi.org /10.1007/s40292-016-0149-0

56. Accomando S: Natural polyphenols as antiinflammatory agents. Front Biosci. 2010 S2(1):318-331. http://dx.doi.org/10.2741/s67

57. Volpe M: High Blood Pressure \& Cardiovascular Prevention. High Blood Press Cardiovasc Prev. 2007 14(1): 1-3. http:/ / dx.doi.org/10.2165/00151642-200714 010-00001

58. Riemersma R: Tea flavonoids and cardiovascular health. QJM 2001 94(5):277282. http://dx.doi.org/10.1093/qjmed/ 94.5.277

59. Pienta K: Bone metastasis and cancer. Cancer Metastasis Rev. 2006 25(4): 505-505. http:/ / dx.doi.org/10.1007/s10555-006-90204

60. Seiler H, Linseisen J, Hermann S, ChangClaude J: S04.4: Dietary intake of flavonoids and phenolic acids and premenopausal breast cancer risk. Biometrical J. 2004 46(S1):10-10. http://dx.doi.org/10.1002/ bimj.200490002

61. Filippis BD, Ammazzalorso A, Fantacuzzi M, Giampietro L, Maccallini C, Amoroso R: Anticancer Activity of Stilbene-Based Derivatives. ChemMedchem. 2017 12(8):558570. http://dx.doi.org/10.1002/cmdc. 201700045

62. Martínez-Medina J, Naso L, Pérez A, Rizzi A, Ferrer E, Williams P: Antioxidant and anticancer effects and bioavailability studies of the flavonoid baicalin and its oxidovanadium(IV) complex. J Inorg Biochem. 2017 166:150-161. http://dx.doi.org/10.1016/ j.jinorgbio.2016.11.005

63. Karjalainen A, Doan $\mathrm{P}$, Sandberg $\mathrm{O}$, Chandraseelan J, Yli-Harja O, Candeias N, et al: Synthesis of phenol-derivatives and biological screening for anticancer activity. Anticancer Agents Med Chem. 2017 17(12): 1710-1720 http://dx.doi.org/10.2174/187 1520617666170327142027

64. Wang Y, Xia C, Zhang W, Zhao Y: Synthesis and biological evaluation of novel lignan glycosides as anticancer agents. Chem Biol Drug Des. $2016 \quad$ 88(4):562-567. http:/ / dx.doi.org/10.1111/cbdd.12785

65. Cui Y, Shi L, Qin H, Liu S: Research progress in mechanisms of the anticancer effects of green tea polyphenol (-)-epigallocatechin-3gallate. Shi Jie Hua Ren Xiao Hua Za Zhi. 2009 17(3):229. http://dx.doi.org/10.11569 /wcjd.v17.i3.229

66. Cui Y, Shi L, Qin H, Liu S: Research progress in mechanisms of the anticancer effects of green tea polyphenol (-)-epigallocatechin-3gallate. Shi Jie Hua Ren Xiao Hua Za Zhi. 2009 17(3):229. http://dx.doi.org/10.11569 /wcjd.v17.i3.229

67. Wiseman H, Kaur H, Halliwell B: DNA damage and cancer: Measurement and mechanism. Cancer Lett.1995, 93(1), 113-120. http:/ /dx.doi.org/10.1016/0304-3835(95) 03792-u

68. Dawson M, Kouzarides T: Cancer Epigenetics: From Mechanism to Therapy. Cell. 2012 150(1):12-27. http://dx.doi.org/ 10.1016/j.cell.2012.06.013

69. Fujiki H, Sueoka E, Watanabe T, Suganuma M: Primary Cancer Prevention by Green Tea, and Tertiary Cancer Prevention by the Combination of Green Tea Catechins and Anticancer Compounds. J Canc Prev. 2015 20(1):1-4. http://dx.doi.org/10.15430/ jcp.2015.20.1.1

70. Dajas F: Life or death: Neuroprotective and anticancer effects of quercetin. $J$ Ethnopharmacol. $2012 \quad$ 143(2):383-396. http://dx.doi.org/10.1016/j.jep.2012.07.005

71. Sole S: An Insight into Antidiabetic Mechanisms of Polyphenol Rich (Catechin, Epicatechin) Tamarind Seeds. BAOJ Pharma Sci. 2015 1(3):1-10. http://dx.doi.org/ 10.24947/2380-5552/1/3/114

72. Truter I: An investigation into antidiabetic medication prescribing in South Africa. J Clin Pharm Ther. 1998 23(6):417-422. http://dx.doi.org/10.1046/j.1365-2710.1998. 00182.x

73. Hassan Z, Yam M, Ahmad M, Yusof A: Antidiabetic Properties and Mechanism of Action of Gynura procumbens Water Extract in Streptozotocin-Induced Diabetic Rats. Molecules. 2010 15(12): 9008 - 9023. http: //dx.doi.org/10.3390/molecules15129008

74. Sole S: An Insight into Antidiabetic Mechanisms of Polyphenol Rich (Catechin, Epicatechin) Tamarind Seeds. BAOJ Pharm Sci. $2015 \quad$ 1(3):1-10. http://dx.doi.org /10.24947/2380-5552/1/3/114

75. Choi SZ, Lee SO, Jang KU, Chung SH, Park $\mathrm{SH}$, Kang HC: Antidiabetic stilbene and anthraquinone derivatives from Rheum undulatum. Arch Pharm Res 2005 28(9):10271030. http://dx.doi.org/10.1007/bf02977396

76. Pandey K, Rizvi S: Role of red grape polyphenols as antidiabetic agents. Integr Med Res. 2014 3(3):119-125. http:// dx.doi.org/10.1016/j.imr.2014.06.001

77. Camougrand N, Rigoulet M: Aging and oxidative stress: studies of some genes 
involved both in aging and in response to oxidative stress. Respir Physiol. 2001 128(3):393-401. http://dx.doi.org/10.1016/ s0034-5687(01)00314-0

78. Golden TR, Hinerfeld DA, Melov S: Oxidative stress and aging: beyond correlation. Aging Cell. 2002 1(2):117-123. http://dx.doi.org/10.1046/j.1474-9728. 2002.00015.x

79. The causes of aging $J$ Anti-aging Med. 1999 2(2):158-159. http://dx.doi.org/10.1089 /rej.1.1999.2.158a

80. Jin D, Fang Y, Ye L, Hu G: Study of antiaging action in CILI juice. Free Radic Biol Med. 1990 9:15. http://dx.doi.org/10.1016/08915849(90)90219-9

81. Leonardi GR, Moreno I, Melo PS, Alencar SM, Silva SAM: Application of phenolic acids in gels: New antioxidants perspective for antiaging effect. JAAD. 2013 68(4):AB21. http://dx.doi.org/10.1016/j.jaad.2012.12.092

82. Hochstein P: Free radicals in molecular biology, aging, and disease. J Free Radic Biol Med. 1985 1(3):239. http://dx.doi.org/ 10.1016/0748-5514(85) $90124-2$

83. Calabrese V, Maines M: Antiaging Medicine: Antioxidants and Aging. Antioxid Redox Signal. $2006 \quad 8 \quad(3-4): 362-364 . \quad$ http:// dx.doi.org/10.1089/ars.2006.8.362

84. Camins A, Junyent F, Verdaguer E, BeasZarate C, Rojas-Mayorquín A, et al: Resveratrol: An Antiaging Drug with Potential Therapeutic Applications in Treating Diseases. Pharmaceuticals. 2009 2(3):194-205. http://dx.doi.org/10.3390/ ph2030194

85. Elufioye T: Ethnomedicinal Study and Screening of Plants Used for Memory Enhancement and Antiaging in Sagamu, Nigeria. Eur J Med Plants. 2012 2(3):262-275. http:/ / dx.doi.org/10.9734/ejmp/2012/1372

86. Su S, Wink M: Natural lignans from Arctium lappa as antiaging agents in Caenorhabditis elegans. Phytochemistry. 2015 117:340-350. http:/ / dx.doi.org/10.1016/j.phytochem.2015 .06 .021

87. Zhang M, Su N, Huang Q, Zhang Q, Wang Y, $\mathrm{Li} \mathrm{J}$, et al: Phosphorylation and antiaging activity of polysaccharide from Trichosanthes peel. J Food Drug Anal. 2017 25(4):976-983 http://dx.doi.org/10.1016/ j.jfda.2016.12.013

88. Simonian N: Oxidative Stress in Neurodegenerative Diseases. Annu Rev Pharmcol Toxicol. 1996 36(1):83-106. http:/ / dx.doi.org/10.1146/annurev.pharmt ox.36.1.83

89. Barreto G, Guedes R: Polyphenols and neurodegenerative diseases. Nutr Neurosci. 2012 15(3):92-93. http://dx.doi.org/10.1179/ 12z.00000000034
90. Gerszon J, Rodacka A, Puchała M: Antioxidant Properties of Resveratrol and its Protective Effects in Neurodegenerative Diseases. Adv Cell Biol. 2014 4(2). http:/ /dx.doi.org/10.2478/acb-2014-0006

91. Hugel HM, Jackson N: Redox Chemistry of Green Tea Polyphenols: Therapeutic Benefits in Neurodegenerative Diseases. Mini-Rev Med Chem. 2012 12(5):380-387. http://dx.doi.org/10.2174/138955712800493 906

92. Sheikh S, Safia, Haque E, Mir S: Neurodegenerative Diseases: Multifactorial Conformational Diseases and Their Therapeutic Interventions. J Neurodegener Dis. 2013 2013:1-8. http://dx.doi.org/ $10.1155 / 2013 / 563481$

93. Persson I: Red wine, white wine, rosé wine, and grape juice inhibit angiotensinconverting enzyme in human endothelial cells. Int J Nutr Pharmacol Neurol Dis. 2013 3(1):17. http://dx.doi.org/10.4103/22310738.1 